This item was submitted to Loughborough's Research Repository by the author.

Items in Figshare are protected by copyright, with all rights reserved, unless otherwise indicated.

\title{
Institutional and resource-based explanations for subsidiary performance
}

\section{PLEASE CITE THE PUBLISHED VERSION}

http://dx.doi.org/10.1111/1467-8551.12169

\section{PUBLISHER}

(c) British Academy of Management. Published by John Wiley \& Sons.

\section{VERSION}

AM (Accepted Manuscript)

\section{PUBLISHER STATEMENT}

This work is made available according to the conditions of the Creative Commons Attribution-NonCommercialNoDerivatives 4.0 International (CC BY-NC-ND 4.0) licence. Full details of this licence are available at: https://creativecommons.org/licenses/by-nc-nd/4.0/

\section{LICENCE}

CC BY-NC-ND 4.0

\section{REPOSITORY RECORD}

Hughes, Mathew, Taman H. Powell, Leanne Chung, and Kamel Mellahi. 2019. "Institutional and Resourcebased Explanations for Subsidiary Performance”. figshare. https://hdl.handle.net/2134/24333. 


\author{
Mathew Hughes ${ }^{1}$ \\ Durham University Business School \\ Durham University \\ Mill Hill Lane \\ Durham DH1 3LB \\ United Kingdom \\ E-mail: mat.hughes@durham.ac.uk \\ Tel: +44-191-334-5906 \\ Taman H. Powell \\ Cardiff Business School \\ Cardiff University \\ Aberconway Building \\ Cardiff CF10 3EU \\ United Kingdom \\ E-mail:powellth@cardiff.ac.uk \\ Tel: +44-2920-870-059 \\ Leanne Chung \\ Cardiff Business School \\ Cardiff University \\ Aberconway Building \\ Cardiff CF10 3EU \\ United Kingdom \\ E-mail: chungl1@cardiff.ac.uk \\ Tel: +44-2920-875-250

\section{Kamel Mellahi} \\ Warwick Business School \\ The University of Warwick \\ Coventry CV4 7AL \\ United Kingdom \\ Email: Kamel.Mellahi@wbs.ac.uk \\ Tel: +44-24-761-51393
}

\footnotetext{
${ }^{1}$ Corresponding author.
} 


\section{Authors' Biopic}

\section{Mathew Hughes}

Dr. Mathew Hughes is Reader in Entrepreneurial Management at Durham University Business School. His research has focused on such topics as entrepreneurial orientation, building the innovative organization, social capital and network-based learning, and top management change. His work is published in such journals as British Journal of Management, Strategic Entrepreneurship Journal, the International Journal of Human Resource Management, Journal of Product Innovation Management and Journal of Business Research.

\section{Taman H. Powell}

Dr. Taman Powell is Lecturer in Strategic Management \& Innovation at Cardiff Business School. His research addresses how organizations create and capture value with a specific focus on knowledge related practices and how organizations can influence these practices to achieve this value creation and capture. He completed his PhD at Warwick Business School, and was an ESRC Post-Doctoral Fellow at Warwick Business School and Harvard Business School.

\section{Leanne Chung}

Dr. Leanne Chung is Lecturer in Human Resource Management and Organizational Behavior at Cardiff Business School. She obtained her PhD degree in International Business and Management from Cambridge Business School, University of Cambridge. Her research interests are international management, China business, and organizational behaviour. She has various publications in these areas including in Journal of International Business Studies.

\section{Kamel Mellahi}

Dr. Kamel Mellahi is Professor of Strategic Management at Warwick Business School. Kamel's research focuses on non-market strategy, strategic failure and renewal, international business strategy, and internationalization strategies of emerging markets firms. He has coedited or co-authored five books and published over 70 scholarly articles. His research has been published in leading strategy and international business journals including Strategic Management Journal, Journal of Management Studies, Academy of Management Perspectives, and Journal of International Business Studies. 


\title{
INSTITUTIONAL AND RESOURCE-BASED EXPLANATIONS FOR SUBSIDIARY PERFORMANCE
}

\begin{abstract}
Addressing calls to integrate insights from institutional theory and the resource-based view, we bring together dual theoretical explanations from institutional theory and the resourcebased view to examine the effectiveness of transfer of practice and human capital development as two routes to subsidiary performance. Our study of Hong Kong firms with subsidiaries in Mainland China shows that both routes positively affect subsidiary performance. However, our data shows that our sampled firms struggled to successfully transfer practices from their parents. We attribute an explanation for this to the characteristics of practices as organizational capabilities in which transfer is made harder by the difficulty in replicating such capabilities. Consequently, developing subsidiary human capital is an important ally to practice transfer as a means to achieve superior subsidiary performance. Our results raise interesting questions about practice transfer and the resource-based view relevant to future scholarly research.
\end{abstract}

Keywords: Transfer of practice, human capital, institutional theory, resource-based view. 


\section{INTRODUCTION}

Studies tend towards competing accounts of subsidiary performance, typically grounded in institutional explanations of the successful transfer of parent practices for internal legitimacy (Chan and Makino, 2007; Kostova and Roth, 2002) or otherwise the development of new or alternative practices for external legitimacy (Lu and Xu, 2006). ${ }^{2}$ But from a resource-based view (RBV), parent firms may persist with the transfer of established organizational practices to draw on resource-based advantages to generate more defendable returns to its subsidiary (Mellahi et al., 2013). The transfer of practice may then indicate that parents seek to capitalize on their reservoir of rare, valuable and difficult-to-imitate advantages to increase subsidiary performance (Dunning, 1988; He, Brouthers and Filatotchev, 2013; Peng, 2001), which points to a resource-based explanation for what otherwise appears to be internal legitimation behaviour (Mellahi et al., 2013).

Alternatively, the subsidiary may develop novel practices towards the same end and for external legitimation. For a subsidiary to create new practices, it must invest in its human capital resources (Björkman and Budhwar, 2007; Peng, 2001) as human capital function as (micro)foundations for new routines and capabilities (Felin, Foss, Heimeriks and Madsen, 2012). While this is rooted in the RBV and the human capital literature (Coff and Kryscynski, 2011), it has connections to institutional theory. Developing human capital strength can counter against the tendency for institutionalized practices to crowd out the search for new alternatives (Yang and Konrad, 2011), which can weaken subsidiary performance (Rugman and Verbeke, 2001). Given these differences, to what extent do transfer of practices and

\footnotetext{
${ }^{2}$ Studies typically focus on 'foreign' subsidiaries but the challenge they face is rooted in institutional variation, and such institutional variations can perpetuate among regions as well as within and across boundaries. For example, "Certainly... there are substantial differences in corporate and managerial behaviour between Mainland China and [Hong Kong]... As 'same culture, different system' examples like Mainland China and Hong Kong illustrate, the impact of institutional differences is sufficient for Hong Kong managers to regard managing operations in the Mainland as problematic” (Child and Warner, 2003, pp.24-25). Child and Warner (2003) cite many others who share their conclusion that regional differences are great among Hong Kong and Mainland China. Indeed, these remain challenging (Li, Karande and Zhou, 2009; McKirdy, 2014). Thus, the reader may wish to think of the subsidiaries in our study as being distant or regional in that respect, in which the object of interest is the institutional variation they face - not too dissimilar to the idea of a foreign subsidiary.
} 
development of human capital strength explain subsidiary performance?

Focusing on this key question, we argue that both institutional theory and the RBV provide theoretical explanations for both the transfer of practices and the development of human capital as routes to subsidiary performance. We advocate an integrative perspective because the pressure of institutional duality (Kostova and Roth, 2002) reduces organizational activity to a response-driven problem, downplaying the value creation aspect of transfer of practice versus human capital development activity. The RBV instead posits that multinational corporations (MNCs) and their subsidiaries can create value by leveraging existing resources or developing new ones to generate resource-based advantages (Brouthers, Brouthers and Werner, 2008).

The literature integrating insights from institutional and RBV perspectives is thin despite repeated calls from international business and strategy scholars (He et al., 2013; Meyer, Estrin, Bhaumki and Peng, 2009; Oliver, 1997; Peng, 2001, 2003; Wright, Filatotchev, Hoskisson and Peng, 2005). Addressing this problem is valuable because integrating insights from both perspectives can yield new insights neither alone could offer. For example, transferring practices for internal legitimacy sacrifices novelty on the assumption that practices transfer in complete ways that replicate the original resource. Transfer success is then fundamental if value is to follow. But developing subsidiary-level human capital offers opportunities to shape new practices best suited to the context of the subsidiary, such that its strength may also yield important returns to performance. We do not purport to integrate both institutional theory and the RBV perspectives into one position or theory. Rather, we believe that drawing explanations from both theories for an integration of insights offers a better way to understand the phenomena of interest.

This study contributes to the important body of research that seeks to untangle predictions of resource-based and institutional perspectives on subsidiary performance. We 
make two important contributions. First, theorizing an integration of insights from institutional and resource-based explanations leads us to suspect a competition in how corporations approach subsidiary performance. For example, while a successful transfer of practice might increase internal legitimacy and leverage what the MNC parent sees as 'core' practices, novel advantages are more likely to emerge from human capital investments (Andersson, Björkman and Forsgren, 2005). We offer a model to address this concern by demonstrating dual institutional and resource-based reasons for practice transfer and human capital routes to subsidiary performance. Bringing together legitimacy-seeking and advantage-seeking behaviour in this manner offers an alternative to traditional conceptualizations of the phenomena under investigation. Second, we offer an empirical model that unpacks the contribution of human capital to subsidiary performance. The human capital of the subsidiary is important for establishing and enacting new practices in pursuit of subsidiary performance, but also offers a direct basis for subsidiary performance by serving as critical resources capable of generating rare advantages and difficult-to-imitate rents (Coff, 1997). This adds new knowledge to how beneficial resource-based advantages may come about within subsidiaries (Brouthers et al., 2008).

The paper now moves to establish the theoretical background for the work.

\section{THEORETICAL BACKGROUND AND HYPOTHESES}

\section{Institutional Theory, the Resource-based View, and Subsidiary Performance}

Institutional theory places emphasis on the normative contexts within which subsidiaries exist (Björkman, Fey and Park, 2007). An understanding of the subsidiary’s internal and external contexts is then needed to appreciate what actions it 'must' take to enable subsidiary performance. The source of greatest institutional pressure (Kostova and Roth, 2002) then creates coercive and mimetic pressures (DiMaggio and Powell, 1983) to adopt practices deemed legitimate by the source of that pressure. A subsidiary’s actions are then a response 
to institutional pressure.

For a subsidiary, considerable pressure flows from the parent to adopt its best practices, ‘tried-and-tested’ over time (Chang, Mellahi and Wilkinson, 2009). Such institutional pressure can lead the subsidiary to harmonize practices with the parent (Kostova and Roth, 2002). The adoption of parent practices provides internal legitimacy for the subsidiary with its corporate parent, rendering its subsequent actions to be 'accepted' or ‘approved’ (Kostova, Roth and Dacin, 2008), lowering its transaction costs (Martinez and Dacin, 1999). However, this assumes that a successful transfer is achieved. ${ }^{3}$

The subsidiary may also come under external institutional pressure to generate new practices that align with its local institutional context (Kostova et al., 2008). But the literature on national business systems (Whitley, 1999) suggests that this pressure is two-fold. Dominant practices set in the MNC parent are shaped by its home business context. These face competing pressures to adapt if applied to a subsidiary in a different business system and institutional context (Edwards and Kuruvilla, 2005). Some of the MNC's practices may not be appropriate for local contexts (Jensen and Szulanski, 2004). External legitimacy pressure can then come from deficits in applying corporate practices in circumstances for which they were not intended. This raises a resource-based argument. While the transfer of practices from the MNC parent is an important means by which the shortage of capabilities can be overcome, their imposition in a different institutional setting is potential damaging (Child, Chung and Davies, 2003).

Valuable practices attractive for transfer are conceived as capabilities (Szulanski, 1996) and the existence of capabilities within firms is one of the principles of the RBV (Helfat and Peteraf, 2003). The RBV carries the assumption that the competitive advantage of

\footnotetext{
${ }^{3}$ Jensen and Szulanski (2004) put forward 'stickiness' to describe transfer difficulty but presented it as a feature calling for practice adaptation. If a practice was part transferred or during the process of transfer required significant local adaptation, the transfer could not be classed as a success from an internal legitimation perspective because its form would no longer resemble that of the parent but instead one more aligned with the external institutional context.
} 
a MNC is contingent on its ability to deploy its existing organizational practices/capabilities or develop new ones (Ghoshal and Bartlett, 1988; Kostova and Roth, 2002). This motivates the MNC parent to transfer capabilities to its subsidiary in an extension of the internalization logic (Teece, 2014). But Birkinshaw (1996) observed that "the engine of subsidiary growth is its distinctive capabilities” (p.467, emphasis added), arguing that anything to the contrary renders a subsidiary uncompetitive. Unlike institutional theory, the RBV places emphasis on organizational heterogeneity for superior performance (Barney and Clark, 2007). Instead of responding to pressurizing institutional stimuli, the subsidiary takes a value creation approach to seek superior performance by generating its own unique resource-based advantages (Brouthers et al., 2008). This trades an assumption of replication for one that values novelty. Human capital resources help subsidiaries conceive and implement new practices (Yang and Konrad, 2011). Human resources generate tacit knowledge in the course of their activities that innovate new routines capable of becoming their own practices and capabilities in time (Felin et al., 2012; Winter, 2000, 2003). For example, Mäkelä, Sumelius, Höglund and Ahlvik (2012) found the experience of HR managers to affect the emergence of HR capabilities in MNC subsidiaries. Developing human capital strength can then counter the tendency for institutionalized practices to crowd out the search for new ways of doing business (Yang and Konrad, 2011). Failure to do so can weaken subsidiary performance (Birkinshaw, 1996; Rugman and Verbeke, 2001).

While the RBV could be seen as more naturally supporting the development of novel practices by the subsidiary, Björkman and Lervik (2007) argue that MNC parent practices can also be viewed as valuable resources that should be replicated at the subsidiary to enhance subsidiary performance. Replicating practices that are 'known' (to the parent) to perform in superior ways (Szulanski, 1996) is attractive and practice transfer requires the 
replication of routines underpinning the capability the practice reflects (Winter, 2003). ${ }^{4}$ Both institutional theory and the RBV therefore provide arguments to support the transfer of practices and human capital development as routes to subsidiary performance. We now move to hypothesize the expected relationships within these pathways.

\section{Transfer of Practice and Performance}

The adoption of parent practices by a subsidiary is driven by ‘institutional duality’ (Kostova and Roth, 2002). Historically, this was thought to be driven by external institutional pressure to legitimize itself in its new host context by adopting local practices or adapting its existing ones; but an alternative view is that the subsidiary faces a dual internal institutional pressure to accept the transfer of organizational 'best’ practices from the MNC parent (Chang et al., 2009; Mellahi et al., 2013).

Institutional explanations propose that the transfer of practice offers the subsidiary legitimacy in the eyes of the parent (Kostova et al., 2008; Mellahi et al., 2013) through its conformance with organizational best practices. The institutional perspective then sees the transfer of practice as being driven by a desire to emulate the practices of this relevant peer to establish the internal legitimacy of the venture. This logic is consistent with the idea of external institutional pressures acting on subsidiaries to adopt local practices, merely that its direction is in the opposite (DiMaggio and Powell, 1983; Meyer and Rowan, 1977).

In recognizing an institutional pressure from within the MNC, Kostova and Roth (2002) and Björkman and Lervik (2007) evoke a resource-based logic for maintaining and extending corporate practices into subsidiaries. Organizational practices can resemble valuable firm-specific resources when the routines that underpin them are established over

\footnotetext{
${ }^{4}$ Capabilities are described as a combination of resources, routines and accompanying knowledge that enable an organization to perform operational activities such as operating, marketing, accounting, HR, sales or manufacturing in superior ways (Teece, 2014; Winter, 2003). These are sometimes termed 'ordinary', 'substantive' or 'operational' capabilities in an effort to distinguish them from 'dynamic' capabilities. Dynamic capabilities often rely on these ordinary or substantive capabilities (Helfat and Peteraf, 2003; Winter, 2003). Dynamic capabilities are outside the scope of this paper.
} 
time, have evolved explicitly through refinement efforts and tacitly through organizational learning, and become a difficult-to-imitate, effective organizational capability (Helfat and Winter, 2011; Winter, 2003). In such instances, parents may seek to replicate these valuable resources into its subsidiary as a basis for superior subsidiary performance (Szulanski, 1996). A resource-based perspective then sees the transfer of practice as a means of capitalizing on firm-specific advantages owing to their rarity and relative inimitability outside the firm (Barney, 1991; Barney and Clark, 2007).

The mere transfer of practice from the parent is not sufficient to improve the performance of the subsidiary. From an institutional theory (institutional duality) and resource-based perspective, the transfer of practice from a parent to its subsidiary is intended to duplicate the practices of the parent to as near a facsimile as possible. As the practice is well-tried as a capability in its experience (RBV), its duplication in the subsidiary makes its activities legitimate and reliable in the eyes of the MNC parent (internal legitimacy) (Chang et al., 2009; Mellahi et al., 2013) and further garners its corporate support (Kostova and Roth, 2002).

Transfer success is relative and not binary. Unsuccessful transfer risks compromising the value of the practice because the routines and tacit knowledge underpinning the practice (Winter, 2000) may have transferred incompletely (Jensen and Szulanski, 2004). Institutional theory ignores the complexity of this transfer although the RBV itself neither speaks sufficiently to this problem. Barney (1991) spoke of ‘imperfect imitability’ as a characteristic of valuable resources but in doing so raised the very prospect of low success transfer. Barney (1991) suggests that firm resources and capabilities can be "imperfectly imitable for one or a combination of three reasons: (a) the ability of a firm to obtain a resource is dependent upon unique historical conditions, (b) the link between the resources possessed by a firm and a firm's sustained competitive advantage is causally ambiguous, or (c) the resource generating 
a firm's advantage is socially complex” (p.107). ${ }^{5}$ These problems are exacerbated when the transfer of practice is patchy and ceremonial instead of strategic (Kostova and Roth, 2002), burdening the subsidiary with practices not suitable to its external institutional context (Child et al., 2003), compromising its external institutional legitimacy. This is the case with nonlocation-bound firm-specific advantages where the value of such practices is "very limited (or even absent altogether) if not connected with complementary assets, external linkages and learning capabilities in the subsidiaries” (Rugman and Verbeke, 2003, p.129).

We expect that practice transfer is an important route to subsidiary performance but we expect transfer success to define the performance rewards of practice transfer activity initiated by the parent. Only then might we expect that a sufficient amount of the routines and tacit knowledge underpinning a practice have been replicated. Thus:

Hypothesis 1: The successful transfer of practices from the parent improves subsidiary performance.

A subsidiary is not an independent entity-if a practice is mandated by the parent, the subsidiary is obligated to comply (Kostova and Roth, 2002). The successful transfer of practice from the parent to its subsidiary depends on the extent to which the subsidiary enacts the prescriptions laid out by the parent (Björkman and Lervik, 2007). The transfer of practice may otherwise only be partial. For example, Szulanski (1996) observed that the process of practice transfer is often only a partial replication of the greater web of relationships among routines and capabilities. Rugman and Verbeke (2003) underscored the significance of location-bound firm-specific advantages, and immobile bundle of complementary practices in limiting the value of transferred practices. Central to this problem is that capabilities consist

\footnotetext{
${ }^{5}$ Should a practice be adapted in the course of transfer in a way that distances it as a facsimile of the parent's, this would compete against the institutional pressure (duality) the parent exerts. As a result, the practice is not then a duplication of that of the parent's and would be seen as an unsuccessful transfer (theoretically) in its eyes. Moreover, if adapted, its properties as a valuable resource are potential lost or at least compromised.
} 
of routines that are founded in part in tacit knowledge (Winter, 2000, 2003). Organizations may overcome this by transferring several practices together but even then routines are subject to a degree of flexibility and change (Feldman and Pentland, 2003), and perhaps necessarily so (Jensen and Szulanski, 2004) to achieve external legitimacy. Organizational control placed on the subsidiary by the parent provides the means to monitor the transfer of practice.

In viewing the transfer of practice in resource terms, practices consist of not only routines that must be transferred, but also tacit knowledge on its use and application. Tacit knowledge is harder to imitate and transfer than routines. The successful transfer of practice is then likely to depend on the extent to which subsidiaries are controlled effectively by the parent (Harzing, 1999) and the appropriateness of the forms of organizational control put in place (Grant, 1996). Organizational controls are normally an internal institutional response to ensure the subsidiary conforms to the wishes of the parent, rendering its actions legitimate and worthy of its continued support (Chan and Makino, 2007; Kostova and Roth, 2002). A practice might then be implemented successfully through performance management policies, including setting performance targets and the use of performance-based rewards and appraisal (Mellahi, Frynas and Collings, 2015). From a RBV then, such organizational control is necessary to ensure accuracy in the transfer of valuable routines that underpin a practice (Szulanski, 1996), and coordinate the transfer of knowledge about the practice to its subsidiary (Björkman, Barner-Rasmussen and Li, 2004).

Organizational controls reflect the extent to which the parent firm uses various formal and informal methods to direct the actions of subsidiary managers and employees. Institutionally, procedures, norms and rules incentivize and provide strategic direction. But organizational controls also serve an important resource-based purpose to inform how a practice might be implemented. For example, Björkman et al. (2004) and Mellahi et al. 
(2015) found evidence that the use of headquarter control can influence inter-unit knowledge transfer. Sufficient organizational controls appear to be a perquisite to the successful transfer of practices from the parent to its subsidiary. Thus:

Hypothesis 2: Organizational controls put in place by the parent are positively related to the successful transfer of practices within the subsidiary.

\section{Human Capital and Performance}

A tension the parent corporation faces in transferring practices is the mimetic and isomorphic tendencies of internal institutionalization (DiMaggio and Powell, 1983; Martinez and Dacin, 1999) versus the need to conceive and implement practices tailored to the market context of the subsidiary (Barney and Clark, 2007), enabling it to go beyond competitive parity as prescribed by the RBV. The transfer and institutionalization of practices can erect barriers to the development of new approaches to business activity (Yang and Konrad, 2011), and impede the formation of new alternatives bespoke to the context, which might weaken subsidiary performance (Rugman and Verbeke, 2001). However, the attributes of the subsidiary's resource base can compensate for this institutional hazard, and assert the benefits of its current practices while encouraging the development of new ones (Björkman and Lervik, 2007; Child et al., 2003; Yang and Konrad, 2011). To conceive and implement new ways of doing things, an investment in human capital is required.

Human capital represents the knowledge, information, ideas and skills of individuals and yields a unique asset capable of generating rents for the firm (Becker, 1964). At the unit level, human capital can be defined as the aggregate of individual human capital within the subsidiary, the strength of which is defined by the knowledge, skill and experience possessed by those in the subsidiary (Wright and McMahan, 2011).

Subsidiaries recruit local talent to acquire human capital suitable for its market context, aiding its external legitimacy (Mellahi et al., 2013). They are sometimes forced to do 
so by the policies of the local government. For example, the Chinese government often requires MNCs to share their technologies with state-owned enterprises as a condition of operating in the country, and to hire and develop local employees and managers in turn (Frynas et al., 2006; Hout and Ghemawat, 2010; Sun et al., 2010). This institutional pressure can undermine a subsidiary as its human capital profile becomes driven by external legitimization instead of its resource needs.

From an institutional theory perspective, relying on human capital strength might simply be a suboptimal response to pressures for external legitimacy. But the RBV offers an extended explanation why human capital strength can instead drive unique performance advantages. For a subsidiary to create new practices, it must possess strong human capital resource (Björkman and Budhwar, 2007; Peng, 2001) to spearhead a search for new alternatives when facing internal institutional pressure to conform (Yang and Konrad, 2011), which is valuable to subsidiary performance (Rugman and Verbeke, 2001). When the parent trusts in the human capital strength of its subsidiary, it may loosen its own institutional constrains for maintaining corporate support. For example, empirical evidence has associated human capital with more effective strategic choices (Finkelstein and Hambrick, 1996), effective strategy implementation (Miller and Lee, 2001) and desirable firm outcomes (Pfeffer, 1994). Establishing human capital strength might offer another route to subsidiary performance. Thus:

Hypothesis 3: Human capital strength is positively related to subsidiary performance.

Employees are crucial to a process of learning within subsidiaries. The human capital of the subsidiary can then shape the flow of knowledge about how routines put in place are made to work, or from which new routines might emerge (Saka-Helmhout, 2007). For example, based on institutional theory, the transfer of practice is geared towards institutionalizing organizational practices that become rule-like in nature (Martinez and 
Dacin, 1999) and ingraining ways to do things seen as legitimate by internal stakeholders (Kostova et al., 2008). But studies suggest that subsidiary performance can be compromised when practices are merely ‘adopted’ but not actually ‘in use’ (Kostova et al., 2008), and Child et al. (2003) warn of the dangers of imposing practices into a subsidiary that operates in an unfamiliar institutional environment to its parent. A subsidiary must then look to augment its human capital strength.

Human capital availability and investing in human capital development is intuitively a resource-based problem. However, attracting local talent to MNCs’ subsidiaries has institutional components. For example, until recently, MNCs and their subsidiaries found it relatively easy to recruit local talent when entering China (Schmidt, 2011). But this has changed markedly with MNCs no longer the destination of choice for Chinese graduates as local/domestic firms professionalize and globalize their activities, offering more senior roles and better promotion prospects (Dewhurst, Pettigrew and Srinivasan, 2012; Schmidt, 2011). This does not mean that outsider firms have 'bad' reputations; rather, the opportunities in local/domestic firms are increasingly more attractive making the recruitment landscape harder. From an institutional standpoint, attracting and investing in human capital is necessary to establish the external legitimacy the subsidiary needs to operate in the external environment, irrespective of the institutional duality to prioritise parent-preferred practices. Those subsidiaries able to increase the availability of human capital and then invest in their development once acquired are better placed to build human capital strength.

There are resource-based advantages to this external institutional pressure, however. For example, the literature on absorptive capacity denotes that resources held by the receiving firm are important to its ability to capitalize on new practices and establish new routes to performance (Cohen and Levinthal, 1990). An absence of quality human capital has the effect of inhibiting performance. In contrast, attracting and developing human capital 
increases their firm-specific attributes to become valuable, rare and inimitable resources in their own right, capable of innovating new practices (Yang and Konrad, 2011). The intangible and socially-complex nature of human capital (Coff, 1997) contributes to organizational heterogeneity and its inimitability increases as it becomes more specific to the context in which it is located (Becker, 1993) and developed (Lepak and Snell, 1999). Thus:

Hypothesis 4: The availability of human capital for the subsidiary is positively related to human capital strength.

Hypothesis 5: Investment in human capital development is positively related to the subsidiary’s human capital strength.

Figure 1 illustrates our theoretical model.

\section{INSERT FIGURE 1 HERE}

\section{RESEARCH METHODS}

\section{The Study Context}

The distinctive historical and economic connection between Hong Kong and Mainland China provides an appropriate research context for our study. Although China resumed sovereignty over Hong Kong on $1^{\text {st }}$ July 1997, 'socialist' China and 'capitalist' Hong Kong have very different legal, regulatory and institutional systems (Chan, 2003; Datamonitor, 2008). These have grown over two centuries of being apart. Their different levels of economic development mean that resource availability, infrastructure and market efficiencies contrast significantly (Li et al., 2009). The 'one country, two systems' model put in place for the reunification (to continue for 50 years after the handover in 1997) perpetuate a complex set of institutions, and their accompanying historical, cultural, lingual, economic, legal and lifestyle 
implications mean that institutional and resource differences persist between the two (Child et al., 2003; McKirdy, 2014).

\section{Sample and Procedure}

The target firms operate in Hong Kong and have business activities (subsidiaries) located across the border in Mainland China. No sampling frame containing the full population of target firms exists. So, the sample was drawn from the membership lists of four major business associations: the Hong Kong General Chamber of Commerce, the Chinese Manufacturing Association of Hong Kong, the Federation of Hong Kong Business Association, and the Hong Kong Small and Medium Business Association. The subsidiaries are defined by the Hong Kong firms that have activities in China. Those firms owned by parents in other countries or Mainland Chinese firms were removed from the sample. The resulting sampling frame contained 2669 firms.

Data collection consisted of a team of 7 trained researchers who visited all respondents to administer the questionnaire. All 2669 firms in the sampling frame were contacted by phone and asked to participate in the study. The process continued until the pool of willing interviewees was exhausted. The respondents were executives who were directly responsible for the management of their China business. Most of them were Hong Kong executives who were based in China, but required to travel frequently between Hong Kong and China. Interviews lasted approximately 90 minutes. The final response of 503 respondents (one per firm) represented an 18.85\% response rate.

Of the 503 respondents, 377 were in manufacturing and 126 in services. Twenty three percent had less than 100 employees in Hong Kong and China, 15\% had 100 to 199 employees, 35\% were medium-sized (200-1000 employees), and 27\% were large companies with over 1000 employees in Hong Kong and China. It is impossible to say how this distribution of firms compares with the target population. However, it is reasonable to assume 
that membership of the business associations is skewed towards larger firms and this possible bias should be kept in mind when interpreting the results. For example, there were 167 companies that reported they had overseas employees and operations based in countries outside Hong Kong and China. Also, 295 companies reported that they had worldwide sales activities. Therefore, the survey results reflect a sizeable portion of Hong Kong firms who are engaged in international business activities in other parts of the world beyond China and Hong Kong.

All measures were collected through the same questionnaire. The possibility of common method bias was tested using Harman's one-factor test (Podsakoff, MacKenzie, Lee and Podsakoff, 2003). A principal components factor analysis on all items yielded 7 factors with eigenvalues greater than 1.0. The results showed that several factors rather than one single factor were identified, and the first factor did not account for a majority of the variance (26\%). We conducted a further test using the 'single factor procedure' recommended by Podsakoff et al. (2003). Goodness-of-fit statistics for the single factor model are shown in Table 3. The Goodness of-Fit Index (GFI) of 0.73 and Non-Normed Index (NNFI) of 0.28 provide evidence that the single factor model does not fit the data well. The improved fit of the alternative and more complex model was statistically significant. Also, the correlation matrix (Table 1) indicates that the correlations are much higher inside the constructs than all other coefficients. This provides evidence of the discriminant validity of the constructs. These evidences suggest that the problems inherent in relying on single respondents are insignificant within the data.

INSERT TABLE 1 HERE

To further test the validity and reliability of the study, the same survey was conducted 
at a later stage with the same 503 previously-studied firms via phone calls, fax communications and emails. Only those companies who had local managers who were based in the China affiliate permanently and were responsible for the key business operations were invited for the same survey (intended as a different manager to the initial respondent). However, only 150 valid responses could be collected, partly since most of the key managers of the Chinese units were still the same managers interviewed at the previous stage. No significant differences were found from the main sample, demonstrating high consistency between the parent firm and the subsidiary in the responses to the questions answered.

\section{Questionnaire Development}

A draft questionnaire was developed to measure the variables in the hypotheses. Suitable measures were largely unavailable. New ones were therefore developed, informed by discussions in focus groups comprising 25 senior managers from Hong Kong firms active in China. All items were in non-simplified Chinese (Cantonese when spoken) and English. Translation and back-translation was used to ensure conceptual equivalence of the alternative versions (Brislin, 1970). All variables operating in the questionnaires were self-reported perceptual measures. This method is particularly suitable in studies related to organizational behaviour and intra-organizational knowledge processes (Foss, Minbaeva, Pedersen and Reinholt, 2009).

To minimize the potential for common method bias, two methods were introduced at this design stage: (1) protecting respondent anonymity to reduce evaluation apprehension and (2) counterbalancing question order (Podsakoff et al., 2003). The first approach encourages respondents to answer honestly and reduces the potential for editing their responses because of social desirability, leniency and acquiescence. The second approach was achieved by carefully separating the question order of the predictor and criterion variables. The draft questionnaire was administered to a focus group of 15 executives, leading to some minor 
amendments. The final version was piloted with a separate group of 50 senior managers.

\section{Measures}

Since the constructs in our model (Figure 2) are unobservable, they must be inferred from measured variables. Thus, a latent variable design with multiple indicators for each construct was chosen. This design allows constructs to be represented by a combination of variables that can be empirically measured. It also enables us to estimate construct measurement error (convergent and discriminant validity) in addition to error in the structural equations among constructs (unexplained variance). Most of the measures (apart from subsidiary performance) were developed taking into account the reflections from the managers' experience through the focus group exercise and relevant literature. All these measures employ anchored 7-point scales. The constructs and their measurement items are shown in Table 2.

\section{INSERT TABLE 2 HERE}

Subsidiary Performance was assessed by three items from Venkatraman and Ramanujam (1986), previously used in English and Chinese by Child et al. (2003). These items measure managers' subjective evaluations of their subsidiary’s success. These measures have been shown to positively associate with relevant objective measures (Beamish and Delios, 1997).

The independent variables were constructed from responses collected through the focus group study with 25 senior managers (providing content validity) and were fully represented in the relevant literature. Organizational control comprised four items measuring the extent to which the parent's managers try to use various formal methods to control and motivate the behaviour of the people in their China activities. Following Grant's (1996) concept of control, procedures, norms and rules must be set up strategically to provide 
direction and incentives for knowledge processes.

Transfer Success was examined by the extent to which the knowledge and skill of each function had been transferred successfully to China affiliates. We asked for the experience of the parent regarding the transfer of practice to the subsidiary in Mainland China to this end. Six areas of functional practices were originally included: accounting, operations, HRM, marketing, purchasing and technical standards. These emerged from our focus group of 25 senior managers from Hong Kong firms active in China (a cohort reflective of our main sample), and were present in the practice transfer literature (e.g., Björkman et al., 2004; Gupta and Govindarajan, 2000; Teece, 2014). Subsequent reliability and factor analysis revealed that operations, accounting and HRM practices had stronger internal consistency. The final analysis therefore used only the items of these three practices. Operating practices can form a capability allowing an organization to perform its activities with minimum resource wastage. Effective operating practices increase efficiency, reduce operating cost and are important for competitive advantage (Wu, Melnyk and Flynn, 2010). HRM practices can generate a high-performing working environment that offers a unique competitive advantage (Wright and McMahan, 1992), motivating its transfer from parent to subsidiary (Mellahi et al., 2013). Accounting practices can form an organizational capability for effective financial management. This enables better and more informed decision-making (Bierman and Smidt, 2003), superior evaluation of opportunities and strategic options (Slater, Reddy and Zwirlein, 1998) and improved management of employee performance (Otley, 1999). The mean and standard deviation of operating $(4.57 ; 1.67)$, accounting $(4.07 ; 1.98)$ and $\operatorname{HRM}(4.25,1.71)$ practices transferred indicate that transfer success was difficult to achieve.

Human Capital Availability comprised two items assessing the extent to which managers were satisfied with the availability of competent managers and employees (as 
human resources) for the China business. Human Capital Development was measured by two items assessing the extent to which managers were satisfied with the development of local managerial skills and local employee skills in China. From the focus group data, Hong Kong managers tend to divide their staff into two main types: general employees, taking mostly supporting functions such as routine administration and operations; and managerial staff, which are usually at more senior levels and take responsibility for managing key functions. Human Capital Strength contained three items measuring the degree of confidence the parent's managers have in the competence of their Mainland Chinese staff at their work.

Age, Size and Industry were selected as control variables as each can impact subsidiary performance. A younger subsidiary may not yet have established itself sufficiently in its new market or accumulated the resources needed to perform effectively. A smaller subsidiary may also face resourcing challenges. Industry may affect the performance of the subsidiary by being more or less turbulent and complex in comparison to others.

\section{Validity and Reliability of Measures}

Hypotheses were tested in an r/lavaan model, enabling us to form the underlying constructs (the measurement model) and to test the structural relationships among these constructs simultaneously. To confirm whether the constructs are internally coherent, three tests were used to check the convergent validity of the constructs (Table 2). These tests are based on the saturated measurement model in which all inter-factor correlations are specified (Jöreskog and Sörbom, 1993). First, a test for the strength of linearity: the $\mathrm{R}^{2}$ values of 0.40 or above exceed the normal threshold of 0.20 (Hair, Anderson, Tatham and Black, 1995) and the zvalues for all items are highly significant and their standardized loadings are strong (above 0.69). Second, a test for construct reliability: all six constructs score 0.79 or above, exceeding the threshold of 0.70 (Gerbing and Anderson, 1988). Third, a test for Average Variance Extracted (AVE) (Fornell and Larcker, 1981): the AVE statistics are all above 0.57, 
exceeding the threshold of 0.50 .

Several measures of discriminant validity were also examined. We confirm that the correlations and casual paths between the latent variables are significantly different from 1 when the confidence interval was set to 99.9\% (Fornell and Larker, 1981). The square root of AVE is larger than the correlation with items belonging to other constructs (Table 1). The validity of the studied constructs are thus supported and the goodness-of-fit statistics for the whole measurement model (GFI $=0.93$, NNFI $=0.88)$ meets the requirements for accepting the model.

\section{The Goodness-of-Fit of the Structural Model}

To build the structural model we specified the causal relations to test the hypotheses. After repeated iterations, a final model generated by the r/lavaan analysis provides a coherent representation of the empirical data. To examine the nomological validity of the model, we draw on multiple indices of overall fit for structural equations (Bollen, 1989; Jöreskog and Sörbom, 1993). The theoretical and hypothesized model (model 3 in Table 3) has a chisquare value of 431.46 (d.f. $=175$ ) and a GFI based on residuals of 0.91 . Both indices represent a good fit of the model to the data (Bollen, 1989). The NNFI value, indicating the proportion of improvement of fit relative to the null model when model parsimony is controlled, also provides a good fit of the model to the data $(\mathrm{NNFI}=0.76)$. The root mean square error of approximation (RMSEA) of 0.05 , exceeding the threshold of 0.08 , further suggest the good fit of the proposed model to the data.

A number of alternate specifications, including the saturated measurement model, were compared with the theoretical one (Table 3). By comparing the different models—using the parsimonious GFI of 0.62 and NFI of 0.81 (with adjustment for the higher degrees of freedom in the theoretical model)—-the theoretical model has a better overall goodness-of-fit than the alternatives and therefore best represents the data. 


\section{RESULTS}

INSERT FIGURE 2 AND TABLE 3 HERE

Figure 2 shows the results of hypothesis testing. The relationship between transfer success and subsidiary performance $(\mathrm{H} 1)$ is positive and significant (coefficient of $0.12, \mathrm{p}<0.01$ ). Hypothesis 3 relating human capital strength to performance is strongly supported $(0.54$, $\mathrm{p}<0.01)$. Control $(\mathrm{H} 2)$ is positively associated with transfer success $(0.62, \mathrm{p}<0.01)$, and human capital availability (H4) and human capital development (H5) are positively related to human capital strength (0.35 and 0.47 respectively, both $\mathrm{p}<0.01)$. For our control variables, age, industry and size of Hong Kong-based staff show no effect on subsidiary performance while size of China-based staff has a small positive effect $(0.15, \mathrm{p}<0.01)$.

\section{DISCUSSION AND CONCLUSION}

Viewing subsidiary performance as a function of competing alternatives artificially distils parent firm investments into control and transfer oriented options versus the development of the subsidiary's human capital resources. We overcome this by examining the effects of both of these important routes to subsidiary performance by integrating dual institutional and resource-based explanations for why a corporation might opt for transferring practice or for developing the human capital strength of its subsidiary. Our results offer a platform to better understand subsidiary performance. Several important findings are noted.

First, transfer success has a significant but somewhat small effect on subsidiary performance. Adopting an institutional explanation based on legitimacy may mask that from a resource-based perspective, the transfer of practices from the parent does not necessarily generate unique and defendable strengths that sufficiently augment subsidiary performance. The data indicates that the respondent firms had considerable variance along the items for the 
'transfer success' construct. The average mean of 4.29 and average standard deviation of 1.78 for the three practices (Table 1) suggest the firms had difficulty in transferring practices from the parent to the subsidiary. An explanation might be found in the idea of replication itself. The transfer of practice mimics but does not exactly replicate parent capabilities or the routines underpinning them, suggesting that the practices rarely exhibited the same fidelity as the originals. High fidelity can be thought of as an accurate and faithful replication or reproduction of the practice being transferred. A practice that is part-transferred or is an inaccurate or unfaithful replica of that of the parent's would lack fidelity. Without fidelity, the value of the practice is potentially compromised because the routines and tacit knowledge underpinning the capability may have transferred incompletely. An investment in human capital can help the subsidiary overcome this deficit and increase subsidiary performance further.

Second, the successful transfer of practice is strongly determined by control systems placed on the subsidiary by its parent. Such controls are based on performance targets, performance-based appraisals and rewards, formal systems, formal procedures and rules and detailed reporting. While the successful transfer of practice provides the subsidiary with legitimacy with its corporate parent, and offers it an opportunity to mimic best practices to develop its initial base of capabilities, the transfer might not fully replicate a parent's capabilities owing to the tacit nature of the routines embedded in practices (Szulanski, 1996; Winter, 2003). Ideas, objects and practices rarely travel in complete forms. Information can be lost and lead a practice to mutate even if on the surface parts of its activities are successfully mimicked (Czarniawska and Sevón, 2005).

Third, human capital strength depends on the human capital available to the subsidiary in its location and the extent to which the subsidiary is willing to invest in developing its human capital. From a theoretical perspective, this brings general human 
capital with non-firm specific knowledge into the subsidiary to help it localize its activities and respond to local institutional pressures, while developing the strength of its firm-specific human capital to generate human resources capable of shaping new and context-specific outcomes for the subsidiary. This brings together both human capital types to explain whether defendable returns to subsidiary performance can occur and why. However, our observations are constrained by the fact that we do not yield insights into the conversion process; but we do put forward that the causal mechanisms are embedded in dual explanations from both institutional theory and the RBV.

We offer two contributions to theory. First, our findings and discussion raise doubts about practice transfer as the sole means of encouraging a high-performing subsidiary. Internally transferred practices remain important, but novel advantages are more likely to emerge from human capital investments at the subsidiary level. We caution against comparing the effects of transfer success and human capital development with one another, however. Both are important routes to subsidiary performance offering legitimacy-seeking and advantage-seeking reasons for their adoption. A more direct approach might be to compare a practice imported from the parent to a similar practice developed by the subsidiary. This is difficult because one reason for resorting to practice transfer is to eliminate the duplication of effort by transferring an ostensibly powerful or established capability from the parent to the subsidiary (Szulanski, 1996). In the relentless pursuit of performance improvement, the subsidiary would avoid fashioning two practices for the same activity. The emergence of new, novel practices relies on human capital (Björkman and Budhwar, 2007; Peng, 2001) as its microfoundations (Felin et al., 2012; Mäkelä et al., 2012) and to ward off suffocating institutional pressure (Yang and Konrad, 2011). The contribution of human capital investments to subsidiary performance relies on the availability of local human capital to recruit as well as on its own initiatives to develop human capital. The 
subsidiary must therefore bring together legitimacy-seeking behaviour and advantage-seeking behaviour.

The transfer of practice research would benefit from adopting this dual perspective to best understand how successful transfer of practice can be achieved, particularly in terms of accurately replicating and duplicating routines underpinning practices rather than just mimicking the activity. There is an intriguing theoretical question here about whether successful transfer requires fidelity in comparison to the original resource or not. Institutional theory suggests that fidelity is needed for the subsidiary to gain legitimacy; the RBV suggests that any change in the practice compromises its properties as a capability. Our contributions call for a new research agenda to examine the problem of fidelity in capability replication and practice transfer.

Second, we sought to offer an empirical model that unpacked the contribution of human capital to subsidiary performance along with the transfer of practice. The human capital of the subsidiary offer a direct basis for performance by serving as critical resources capable of generating rare advantages and difficult-to-imitate (and erode) rents. Investing in human capital strength is to invest in the human assets capable of generating new and novel practices bespoke to the context of the subsidiary and to combat constrains to the search for new alternatives. Our findings show the merits of this in terms of returns to subsidiary performance. This suggests a need to account for a knowledge-based view of the parentsubsidiary relationship to go with the RBV and institutional theory. In the knowledge-based view, knowledge is central to the development of organizational capabilities (Grant, 1996). But knowledge resides within human capital.

\section{Limitations and Future Research}

Some limitations constrain our contributions. First, future studies should examine control and human capital in greater detail than was possible in this paper. For example, we did not 
explicitly examine what new practices may have come from the human capital of the subsidiary. We treated it as one part of the causal mechanism through which human capital affects subsidiary performance, explaining why subsidiaries would purposefully invest in developing human capital strength as opposed to just owning human capital resources. A microfoundations view might shed light on these issues (Felin et al., 2012). Second, the limitation of using perceptual measures might be replaced by other sources of data that capture our constructs objectively. This is not straightforward. Determining objective proxies for these 'soft' constructs is difficult and scholars should be mindful of measurement malaise (Ketchen, Ireland and Baker, 2013). It would also be desirable to collect data at both the parent and subsidiary simultaneously. Our wider survey captured some of this and we considered controlling for whether the transfer of a practice was a parental policy or not. We chose not to because the institutional environment could have informed a transfer effort beyond parental policy. Third, a longitudinal research design might benefit investigations surrounding the successful transfer of practices and human capital development. Such research could also investigate whether dynamic capabilities protect against the erosion of advantage from parent or subsidiary capabilities over time (Teece, 2014). Insights from internalization theory (Buckley and Casson, 1976; Hennart, 1982; Hymer, 1976; Rugman, 1981) could also contribute towards understanding these issues. Space limitations do not permit a full evaluation of the contribution of internalization theory to our research question. Future studies incorporating insights from internalization theory are warranted. Finally, the estimated model is based on Hong Kong firms in the China market context. The extent to which the results can be generalized to other contexts needs to be investigated before wider conclusions can be drawn.

Future research would benefit from a focus on both parent and subsidiary as codevelopers of competitive advantage and subsidiary performance (see also Edwards, 
Sanchez-Mangas, Bélanger and McDonnell, 2015). The diffusion of knowledge, routines and practices to set in place an initial set of capabilities for the subsidiary is important but needs to be matched with strategic initiatives supporting human capital strength at the subsidiary level. Such studies could examine the causal effect between human capital and the emergence of new practices. Also, our parsimonious model treats practices (and capabilities) as developing in the headquarters and then transferred to a subsidiary. But in geocentric and polycentric types of organizations, practice development may happen in collaboration with different entities and the subsidiary may have taken part in the development of knowledge about a practice, the practice itself, adapted the transfer of a practice on purpose, or reverse transferred practices to its parent. An extension would be to examine the effects of specific managerial actions in both parent and subsidiary on knowledge transfer when transferring practices. Thus suggests a need to integrate insights from the knowledge-based view along with those from the RBV and institutional theory to better understand the parent-subsidiaryperformance relationship. Under knowledge-based theory, the role of the organization is to create, store and deploy knowledge. How human capital act as integrators of knowledge might be important to resolving the practice transfer problem.

An expanded focus on the composition of subsidiary human capital is also warranted. Expatriates at the subsidiary could be important facilitators of the transfer of practice and carry with them a degree of residual legitimacy if they were previously employed within the parent firm. Expatriates might therefore be a contingency factor relevant to our model. An examination of this issue could also go beyond expatriates to account for different forms of talent within the global talent portfolio of the MNC—such as corporate, subsidiary, international and local talents (Morris, Snell and Björkman, 2015).

Research in strategy and management science would benefit from developing further the notion of fidelity in the context of practice (or capability) transfer. There may be 
instances when adaptation is necessary for success (Jensen and Szulanski, 2004).

Theoretically, this sits awkwardly with the idea of an institutional duality and implies a resource imperative as a way of reconciling institutional tensions. Nevertheless, future studies must embrace the implication that practices transfer in incomplete ways. One reason might be due to the incomplete transfer of the tacit knowledge and routines underpinning practices. Control and trust building are managerial actions relevant to knowledge transfer efforts. Problems with the value and fidelity of practices transferred might also be due to a lack of fit with the institutional environment of the subsidiary. Our study design partially controls for this by studying transfer success and entry by a set of firms from only one origin (Hong Kong) to only one destination (Mainland China). These are important new directions for future research.

\section{Conclusion}

Addressing repeated calls from international business and strategy scholars to integrate insights from institutional and resource-based views, this study answers the question, 'to what extent do transfer of practice and developing human capital strength explain subsidiary performance?' The variance in transfer success reported by our respondents indicates that while valuable, rare and difficult-to-imitate resources exist within MNC parents potentially of value to its subsidiaries, unless we collectively identify the means to successfully transfer those practices, their relative inimitability stretches not only to competitors but also to the MNC's own subsidiaries. Transfer success rendered a positive but smaller contribution to subsidiary performance than might be hoped. A subsidiary can use human capital strategies as a further pathway to superior performance. While we move forward knowledge on subsidiary performance, the integration of insights from institutional theory and the RBV can advance the field and management practice yet further. 


\section{REFERENCES}

Andersson, U., I. Björkman and M. Forsgren (2005). ‘Managing subsidiary knowledge creation: the effect of control mechanisms on subsidiary local embeddedness', International Business Review, 14(5), pp.521-538.

Barney, J. B. (1991). 'Firm resources and sustained competitive advantage', Journal of Management, 17(1), pp.99-121.

Barney, J. B. and D. N. Clark (2007). Resource-based Theory: Creating and Sustaining Competitive Advantage. Oxford: Oxford University Press.

Beamish, P.W. and A. Delios (1997). 'Improving joint venture performance through congruent measures of success', in P.W. Beamish and J.P. Killing (eds.), Cooperative Strategies: European Perspectives. San Francisco: New Lexington Press, pp.103-127.

Becker, G. S. (1964). Human Capital. New York: Columbia University Press.

Becker, G. S. (1993). 'Nobel lecture: the economic way of looking at behavior', The Journal of Political Economy, 101(3), pp.385-409.

Bierman, Jr., H. and S. Smidt (2003). Financial Management for Decision Making. Washington, DC: Beard Books.

Birkinshaw, J. (1996). 'How multinational subsidiary mandates are gained and lost', Journal of International Business Studies, 27(3), pp.467-495.

Björkman, I. and P. Budhwar (2007). 'When in Rome...?: Human resource management and the performance of foreign firms operating in India', Employee Relations, 29(6), pp.595610.

Björkman, I. and J. E. Lervik (2007). ‘Transferring HR practices within multinational corporations', Human Resource Management Journal, 17(4), pp.320-335.

Björkman, I., W. Barner-Rasmussen and L. Li (2004). 'Managing knowledge transfer in MNCs: the impact of headquarters control mechanisms', Journal of International Business 
Studies, 35(5), pp.443-455.

Björkman, I., C. F. Fey and H. J. Park (2007). 'Institutional theory and MNC subsidiary HRM practices: evidence from a three-country study', Journal of International Business Studies, 38(3), pp.430-446.

Bollen, K. A. (1989). Structural Equations with Latent Variables. New York: Wiley.

Brislin, R. (1970) 'Back-translation for cross-cultural research', Journal of Cross-Cultural Psychology, 1(3), 185-216.

Brouthers, K. D., L. E. Brouthers and S. Werner (2008). 'Resource-based advantages in an international context', Journal of Management, 34, pp.189-217.

Buckley, P. and M. Casson (1976). The Future of the Multinational Enterprise. London: Macmillan.

Chan, H. S. (2003). 'The civil service under one country, two systems: the cases of Hong Kong and the People's Republic of China', Public Administration Review, 63, pp. 405417.

Chan, C. M. and S. Makino (2007). 'Legitimacy and multi-level institutional environments: implications for foreign subsidiary ownership structure', Journal of International Business Studies, 38(4), pp.621-638.

Chang, Y. Y., K. Mellahi and A. Wilkinson (2009). 'Control of subsidiaries of MNCs from emerging economies in developed countries: the case of Taiwanese MNCs in the UK', International Journal of Human Resource Management, 20(1), pp.75-95.

Child, J. and M. Warner (2003). 'Culture and management in China’, in M. Warner (Ed.), Culture and Management in Asia. London: RoutledgeCurzon, pp.24-47.

Child, J., L. Chung and H. Davies (2003). 'The performance of cross-border units in China: a test of natural selection, strategic choice and contingency theories', Journal of International Business Studies, 34(3), pp.242-254. 
Coff, R. (1997). 'Human assets and management dilemmas: coping with hazards on the road to resource-based theory', Academy of Management Review, 22(2), pp.374-402.

Coff, R. and D. Kryscynski (2011). 'Drilling for micro-foundations of human capital-based competitive advantages', Journal of Management, 37, pp.1429-1443.

Cohen, W. M. and D. A. Levinthal (1990). 'Absorptive capacity: a new perspective on learning and innovation’, Administrative Science Quarterly, 35(1), pp.128-152.

Czarniawska, B. and G. Sevón (2005). Global Ideas: How Ideas, Objects and Practices Travel in the Global Economy. Copenhagen: Liber/CBS.

Datamonitor (2008). 'Political landscape’, Hong Kong Country Profile, September, pp.28-35.

Dewhurst, M., M. Pettigrew and R. Srinivasan (2012). 'How multinationals can attract the talent they need’, McKinsey Quarterly, Issue 3, p92-99.

DiMaggio, P. J. and W. W. Powell (1983). ‘The iron cage revisited: institutional isomorphism and collective rationality in organizational fields', American Sociological Review, 48(2), pp.147-160.

Dunning, J. H. (1988). 'The eclectic paradigm of international production: a restatement and some possible extensions', Journal of International Business Studies, 19, pp.1-31.

Edwards, T. and S. Kuruvilla (2005). 'International HRM: national business systems, organizational politics and the international division of labour in MNCs', International Journal of Human Resource Management, 16(1), pp.1-21.

Edwards, T., R. Sanchez-Mangas, J. Bélanger and A. McDonnell (2015). 'Why are some subsidiaries of multinationals the source of novel practices while others are not? National, corporate and functional influences’, British Journal of Management, forthcoming.

Feldman, M. S. and B. T. Pentland (2003). 'Reconceptualizing organizational routines as a source of flexibility and change’, Administrative Science Quarterly, 48(1), pp.94-118. Felin, T., N. Foss, K. Heimeriks and T. Madsen (2012). 'Microfoundations of routines and 
capabilities: individuals, processes, and structure', Journal of Management Studies, 49, pp.1351-1374.

Finkelstein, S. and D. Hambrick (1996). Strategic Leadership. St. Paul: West.

Fornell, C. and D. Larcker (1981). 'Evaluating structural equation models with unobservable variables and measurement error', Journal of Marketing Research, 18(1), 39-50.

Foss, N. J., D. B. Minbaeva, T. Pedersen and M. Reinholt (2009). 'Encouraging knowledge sharing among employees: how job design matters’, Human Resource Management, 48(6), pp.871- 893.

Frynas, J. G., K. Mellahi and G. Pigman (2006). 'First mover advantages in international business and firm-specific political resources’, Strategic Management Journal, 27, pp.321-345.

Gerbing, D. and J. Anderson (1988). ‘An updated paradigm for scale development incorporating unidimensionality and its assessment', Journal of Marketing Research, 25(2), pp.186-192.

Ghoshal, S. and C. A. Bartlett (1988). 'Creation, adoption, and diffusion of innovations by subsidiaries of multinational corporations’, Journal of International Business Studies, 19(3), pp.365-388.

Grant, R. (1996). ‘Toward a knowledge-based theory of the firm', Strategic Management Journal, 17(Winter Special Issue), pp.109-122.

Gupta, A. K. and V. Govindarajan (2000). ‘Knowledge flows within multinational corporations’, Strategic Management Journal, 21(4), 473-496.

Hair, J., R. Anderson, R. Tatham and W. Black (1995). Multivariate Data Analysis with Readings (4th ed.). Englewood Cliffs, NJ: Prentice-Hall.

Harzing, A.-W. K. (1999). Managing the Multinationals: An International Study of Control Mechanisms. Cheltenham: Edward Elgar. 
He, X., K. D. Brouthers and I. Filatotchev (2013). 'Resource-based and institutional perspectives on export channel selection and export performance', Journal of Management, 39(1), pp.27-47.

Helfat, C. E. and M. A. Peteraf (2003). 'The dynamic resource-based view: capability life cycles’, Strategic Management Journal, 24, pp.997-1010.

Helfat, C. E. and S. G. Winter (2011). 'Untangling dynamic and operational capabilities: strategy for the (n)ever-changing world', Strategic Management Journal, 32(11), pp.12431250.

Hennart, J. F. (1982). A Theory of Multinational Enterprise. Ann Arbor: University of Michigan Press.

Hout, T. and P. Ghemawat (2010). 'China vs the world: whose technology is it?', Harvard Business Review, 88(12), pp.94-103.

Hymer, S. H. (1976). The International Operations of National Firms: A Study of Direct Foreign Investment. Cambridge, MA: MIT Press.

Jensen, R. and G. Szulanski (2004). 'Stickiness and the adaptation of organizational practices in cross-border knowledge transfers', Journal of International Business Studies, 35(6), pp.508-523.

Jöreskog, K. and D. Sörbom (1993). LISREL 8: Structural Equation Modeling with the SIMPLIS Command Language. Hillsdale, NJ: Lawrence Erlbaum.

Ketchen, Jr., D. J., R. D. Ireland and L. T. Baker (2013). 'The use of archival proxies in strategic management studies: castles made of sand?’, Organizational Research Methods, 16(1), pp.32-42.

Kostova, T. and K. Roth (2002). 'Adoption of an organizational practice by subsidiaries of multinational corporations: institutional and relational effects', Academy of Management Journal, 45(1), pp.215-233. 
Kostova, T., K. Roth and M. T. Dacin (2008). 'Institutional theory in the study of multinational corporations: a critique and new directions', Academy of Management Review, 33(4), pp.994-1006.

Lepak, D.P. and S. A. Snell (1999). 'The human resource architecture: toward a theory of human capital allocation and development', Academy of Management Review, 24, pp.3148.

Li, S., K. Karande and D. Zhou (2009). 'The effect of the governance environment on marketing channel behaviors: the diamond industries in the U.S., China, and Hong Kong', Journal of Business Ethics, 88(3), pp.453-471.

Lu, J. W. and D. Xu (2006). 'Growth and survival of international joint ventures: An external-internal legitimacy perspective’, Journal of Management, 32(3), pp.426-448.

Mäkelä, K., J. Sumelius, M. Höklund and C. Ahlvik (2012). 'Determinants of strategic HR capabilities in MNC subsidiaries’, Journal of Management Studies, 49(8), pp.1459-1483.

Martinez, R. J. and M. T. Dacin (1999). 'Efficiency motives and normative forces: combining transactions costs and institutional logic', Journal of Management, 25(1), pp.75-96.

McKirdy, E. (2014). “'One country, two systems’: how Hong Kong remains distinct from China’, CNN, 30 September 2014, available at: http://edition.cnn.com/2014/09/29/world/asia/hong-kong-protest-backgrounder/

Mellahi, K., M. Demirbag, D. G. Collings, E. Tatoglu and M. Hughes (2013). 'Similarly different: a comparison of HRM practices in MNE subsidiaries and local firms in Turkey’, International Journal of Human Resource Management, 24(12), pp.2339-2368.

Mellahi, K., J.G. Frynas and D. Collings (2015). 'Performance management practices within emerging market multinational enterprises: the case of Brazilian multinationals', International Journal of Human Resource Management, DOI:10.1080/09585192.2015.1042900 
Meyer, J. W. and B. Rowan (1977). 'Institutionalized organizations: formal structure as myth and ceremony', American Journal of Sociology, 83, pp.340-363.

Meyer, K. E., S. Estrin, S. K. Bhaumik and M. W. Peng (2009). 'Institutions, resources and entry strategies in emerging economies’, Strategic Management Journal, 30, pp.61-80.

Miller, D. and J, Lee (2001). 'The people make the process: commitment to employees, decision making, and performance', Journal of Management, 27(2), pp.163-189.

Morris, S., S. Snell, and I. Björkman (2015). 'An architectural framework for global talent management', Journal of International Business Studies, forthcoming.

Oliver, C. (1997). 'Sustainable competitive advantage: combining institutional and resourcebased views’, Strategic Management Journal, 18(9), pp.697-713.

Otley, D. (1999). 'Performance management: a framework for management control systems research', Management Accounting Research, 10, pp.363-382.

Peng, M. W. (2001). 'The resource-based view and international business', Journal of Management, 27(6), pp.803-829.

Peng, M. W. (2003). 'Institutional transitions and strategic choices’, Academy of Management Review, 28, pp.275-296.

Pfeffer, J. (1994). Competitive Advantage through People. Boston: Harvard Business School Press.

Podsakoff, P. M., S. B.MacKenzie, J.-Y. Lee and N. P. Podsakoff (2003). 'Common method bias in behavioral research: a critical review of the literature and recommended remedies', Journal of Applied Psychology, 88(5), pp. 879-903.

Rugman, A. M. (1981). Inside the Multinationals: The Economics of Internal Markets. New York: Columbia University Press.

Rugman, A. M. and A. Verbeke (2001). 'Subsidiary-specific advantages in multinational enterprises’, Strategic Management Journal, 22(3), pp.237-250. 
Rugman, A. M. and A. Verbeke (2003). 'Extending the theory of the multinational enterprise: internalization and strategic management perspectives', Journal of International Business Studies, 34(2), pp.125-137.

Saka-Helmhout, A. (2007). 'Unravelling learning within multinational corporations’, British Journal of Management, 18, pp.294-310.

Schmidt, C. (2011). 'The battle for China’s talent', Harvard Business Review, 89(3), pp.2527.

Slater, S. F., V. K. Reddy and T. J. Zwirlein (1998). 'Evaluating strategic investments: complementing discounted cash flow analysis with options analysis’, Industrial Marketing Management, 27, pp.447-458.

Sun, P., K. Mellahi and E. Thun (2010). 'The dynamic value of MNE political embeddedness: The case of the Chinese automobile industry', Journal of International Business Studies, 41(7), pp.1161-1182.

Szulanski, G. (1996). 'Exploring internal stickiness: impediments to the transfer of best practice within the firm', Strategic Management Journal, 17(S2), pp.27-43.

Teece, D. J. (2014). 'A dynamic capabilities-based entrepreneurial theory of the multinational enterprise', Journal of International Business Studies, 45, pp.8-37.

Venkatraman, N. and V. Ramanujam (1986). 'Measurement of business performance in strategy research: a comparison of approaches', Academy of Management Review, 11(4), pp.801-814.

Whitley. R. (1999). Divergent Capitalisms: The Social Structuring and Change of Business Systems. Oxford: Oxford University Press.

Winter, S. G. (2000). 'The satisficing principle in capability learning', Strategic Management Journal, 21(10-11), pp.981-996.

Winter, S. G. (2003). 'Understanding dynamic capabilities’, Strategic Management Journal, 
24(10), pp.991-995.

Wright, M., I. Filatotchev, R. E. Hoskisson, and M. W. Peng (2005). 'Strategy research in emerging economies: challenging the conventional wisdom', Journal of Management Studies, 26, pp.1-34.

Wright, P. M. and G. C. McMahan (1992). 'Theoretical perspectives for strategic human resource management', Journal of Management, 18(2), pp.295-320.

Wright, P. M. and G. C. McMahan (2011). ‘Exploring human capital: putting human back into strategic human resource management', Human Resource Management Journal, 21(2), pp.93-104.

Wu, S. J., S. A. Melnyk and B. B. Flynn (2010). 'Operational capabilities: the secret ingredient’, Decision Sciences, 41(4), pp.721-754.

Yang, Y. and A. M. Konrad (2011). 'Understanding diversity management practices: implications of institutional theory and resource-based theory', Group and Organization Management, 36(1), pp.6-38. 


\section{Figure 1. Theoretical Model}

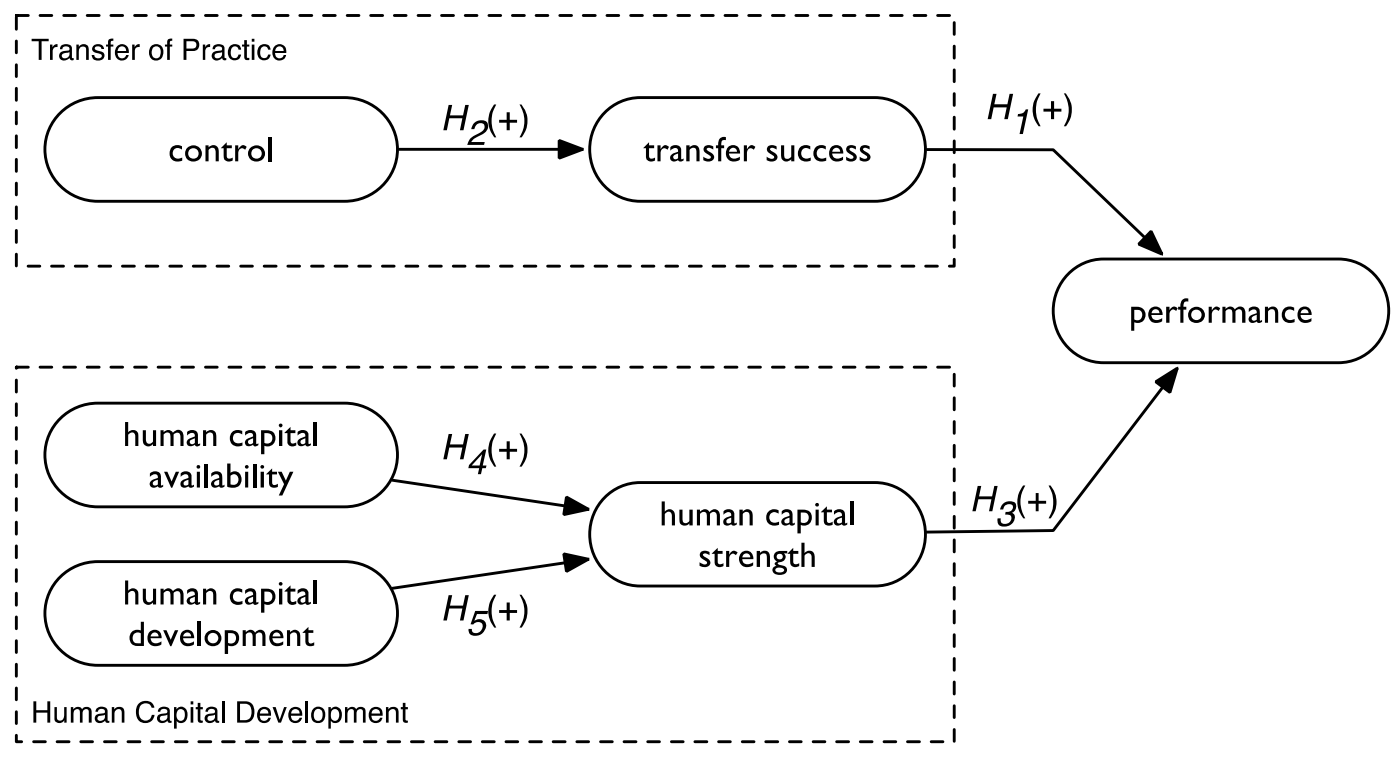

\section{Figure 2. Empirical Model}

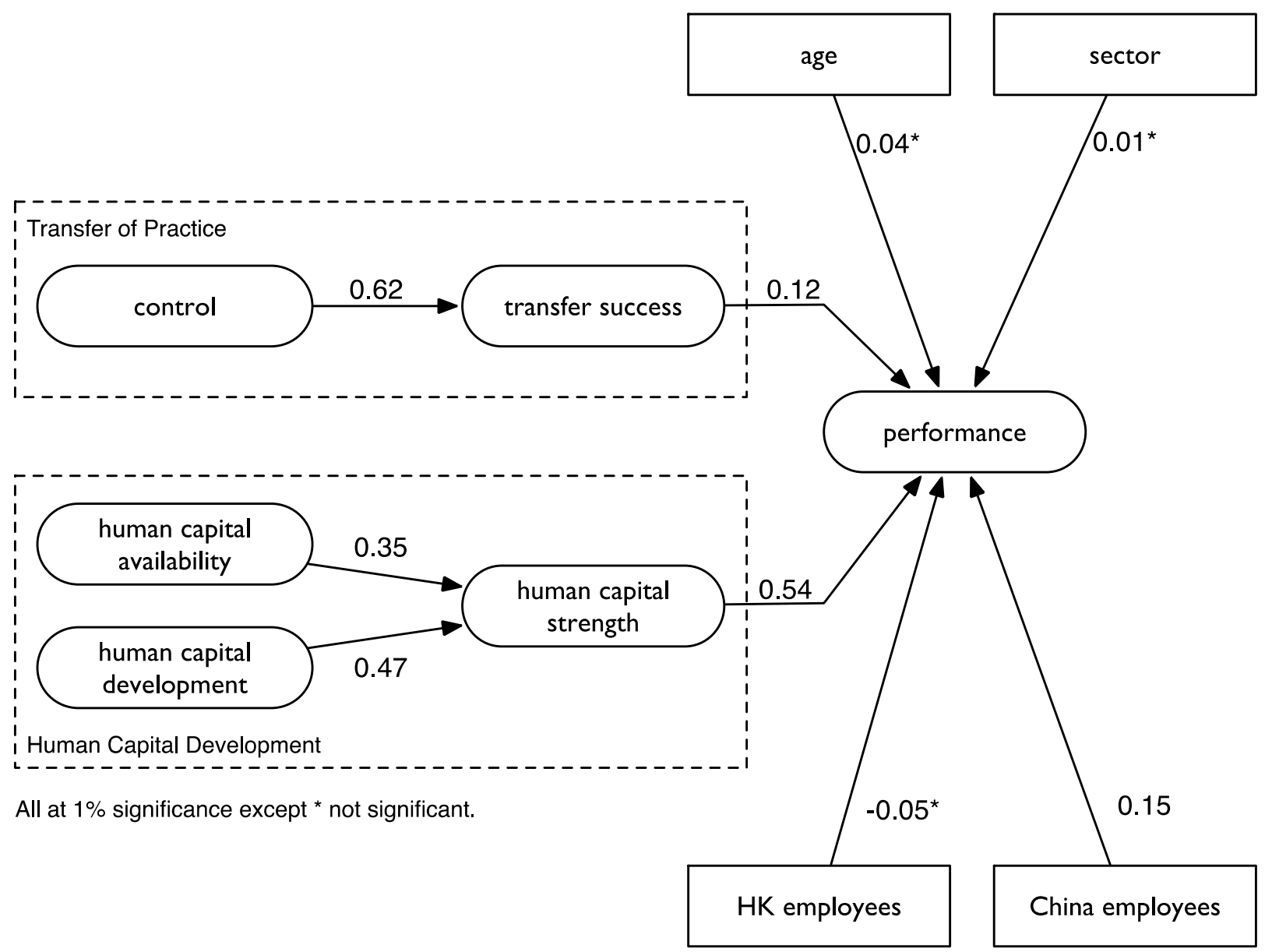




\section{Table 1. Correlation Matrix $(\mathrm{N}=615)$}

\begin{tabular}{|c|c|c|c|c|c|c|c|c|c|c|c|c|c|c|c|c|c|c|c|c|c|}
\hline & 1 & 2 & 3 & 4 & 5 & 6 & 7 & 8 & 9 & 10 & 11 & 12 & 13 & 14 & 15 & 16 & 17 & 18 & 19 & 20 & 21 \\
\hline $\begin{array}{l}\text { 1. Setting performance } \\
\text { targets }\end{array}$ & 0.67 & & & & & & & & & & & & & & & & & & & & \\
\hline $\begin{array}{l}\text { 2. Use performance- } \\
\text { related rewards, } \\
\text { appraisals }\end{array}$ & $0.67^{* * *}$ & 0.67 & & & & & & & & & & & & & & & & & & & \\
\hline $\begin{array}{l}\text { 3. Use formal systems, } \\
\text { procedures and rules }\end{array}$ & $0.73^{* * *}$ & $0.64^{* * *}$ & 0.67 & & & & & & & & & & & & & & & & & & \\
\hline $\begin{array}{l}\text { 4. Detailed reporting } \\
\text { on operations }\end{array}$ & $0.64^{* * *}$ & $0.59^{* * *}$ & $0.67^{* * *}$ & 0.67 & & & & & & & & & & & & & & & & & \\
\hline $\begin{array}{l}\text { 5. Transferring } \\
\text { operating practices }\end{array}$ & $0.31^{* * *}$ & $0.33^{* * *}$ & $0.31^{* * *}$ & $0.35^{* * *}$ & 0.80 & & & & & & & & & & & & & & & & \\
\hline $\begin{array}{l}\text { 6. Transferring } \\
\text { accounting practices }\end{array}$ & $0.35^{* * *}$ & $0.33^{* * *}$ & $0.30^{* * *}$ & $0.31^{* * *}$ & $0.57^{* * *}$ & 0.80 & & & & & & & & & & & & & & & \\
\hline $\begin{array}{l}\text { 7. Transferring HRM } \\
\text { practices }\end{array}$ & $0.30^{* * *}$ & $0.34^{* * *}$ & $0.33^{* * *}$ & $0.34^{* * *}$ & $0.75^{* * *}$ & $0.54^{* * *}$ & 0.80 & & & & & & & & & & & & & & \\
\hline $\begin{array}{l}\text { 8. Competent } \\
\text { employees available }\end{array}$ & $0.10^{* *}$ & 0.06 & $0.09^{* *}$ & 0.03 & $0.12^{* * *}$ & $0.08^{* *}$ & $0.13^{* * *}$ & 0.85 & & & & & & & & & & & & & \\
\hline $\begin{array}{l}\text { 9. Competent } \\
\text { managers available }\end{array}$ & 0.01 & 0.07 & 0.00 & -0.03 & $0.11^{* *}$ & 0.03 & $0.16^{* * *}$ & $0.69^{* * *}$ & 0.85 & & & & & & & & & & & & \\
\hline $\begin{array}{l}\text { 10. Development of } \\
\text { local managerial } \\
\text { skills }\end{array}$ & $0.10^{* *}$ & $0.12^{* * *}$ & $0.08^{*}$ & $0.10^{* *}$ & $0.20^{* * *}$ & $0.18^{* * * *}$ & $0.22^{* * *}$ & $0.43^{* * *}$ & $0.50^{* * *}$ & 0.73 & & & & & & & & & & & \\
\hline $\begin{array}{l}\text { 11. Development of } \\
\text { local employee skills }\end{array}$ & $0.13^{* * *}$ & $0.09^{* *}$ & $0.08^{*}$ & $0.07^{*}$ & $0.22^{* * *}$ & $0.20^{* * * *}$ & $0.24^{* * *}$ & $0.51^{* * * *}$ & $0.44^{* * *}$ & $0.74^{* * *}$ & 0.73 & & & & & & & & & & \\
\hline $\begin{array}{l}\text { 12. Staff will always do } \\
\text { a good job }\end{array}$ & 0.02 & 0.06 & 0.03 & 0.04 & 0.06 & $0.09^{* *}$ & $0.10^{* *}$ & $0.46^{* * *}$ & $0.47^{* * *}$ & $0.47^{* * *}$ & $0.51^{* * *}$ & 0.68 & & & & & & & & & \\
\hline 13. Can trust our staff & 0.05 & 0.05 & 0.04 & 0.05 & $0.10^{* *}$ & $0.09^{* *}$ & $0.12^{* * *}$ & $0.41^{* * *}$ & $0.44^{* * *}$ & $0.44^{* * *}$ & $0.45^{* * *}$ & $0.63^{* * *}$ & 0.68 & & & & & & & & \\
\hline $\begin{array}{l}\text { 14. Can delegate to our } \\
\text { staff }\end{array}$ & $0.07^{*}$ & $0.08^{* *}$ & 0.04 & 0.05 & $0.11^{* *}$ & $0.08^{* *}$ & $0.10^{* *}$ & $0.38^{* * *}$ & $0.46^{* * *}$ & $0.50^{* * *}$ & $0.46^{* * *}$ & $0.72^{* * *}$ & $0.67^{* * *}$ & 0.68 & & & & & & & \\
\hline $\begin{array}{l}\text { 15. Success in meeting } \\
\text { strategic objectives }\end{array}$ & $0.16^{* * *}$ & $0.17^{* * *}$ & $0.12^{* * *}$ & $0.19^{* * *}$ & $0.15^{* * *}$ & $0.20^{* * *}$ & $0.18^{* * *}$ & $0.30^{* * *}$ & $0.27^{* * *}$ & $0.41^{* * *}$ & $0.37^{* * *}$ & $0.38^{* * *}$ & $0.37^{* * *}$ & $0.37^{* * *}$ & 0.56 & & & & & & \\
\hline $\begin{array}{l}\text { 16. Satisfaction with } \\
\text { performance }\end{array}$ & $0.15^{* * *}$ & $0.16^{* * *}$ & $0.12^{* * *}$ & $0.14^{* * *}$ & $0.14^{* * *}$ & $0.12^{* * *}$ & $0.17^{* * * *}$ & $0.29^{* * *}$ & $0.29^{* * *}$ & $0.39^{* * *}$ & $0.38^{* * *}$ & $0.40^{* * *}$ & $0.38^{* * *}$ & $0.35^{* * *}$ & $0.71^{* * *}$ & 0.56 & & & & & \\
\hline $\begin{array}{l}\text { 17. Satisfaction } \\
\text { compared to } \\
\text { competitors }\end{array}$ & $0.17^{* * *}$ & $0.15^{* * *}$ & $0.13^{* * *}$ & $0.16^{* * *}$ & $0.20^{* * *}$ & $0.17^{* * *}$ & $0.19^{* * *}$ & $0.24^{* * *}$ & $0.22^{* * *}$ & $0.29 * * *$ & $0.32^{* * *}$ & $0.33^{* * *}$ & $0.33^{* * *}$ & $0.30^{* * *}$ & $0.65^{* * *}$ & $0.63^{* * *}$ & 0.56 & & & & \\
\hline 18. Age & -0.06 & -0.05 & $-0.10^{* *}$ & $-0.11^{* *}$ & $-0.08^{* *}$ & -0.01 & -0.06 & 0.03 & -0.01 & -0.02 & 0.02 & 0.04 & 0.05 & -0.01 & 0.03 & 0.05 & 0.06 & & & & \\
\hline
\end{tabular}




\begin{tabular}{|c|c|c|c|c|c|c|c|c|c|c|c|c|c|c|c|c|c|c|c|c|c|}
\hline 19. Sector & 0.06 & $0.15^{* * *}$ & $0.11^{* * *}$ & $0.10^{* *}$ & $0.08^{* *}$ & -0.02 & $0.08^{* *}$ & -0.02 & $0.08^{*}$ & $0.08^{*}$ & 0.02 & 0.00 & -0.04 & 0.02 & 0.06 & $0.08^{* *}$ & -0.01 & $-0.12 * * *$ & & & \\
\hline 20. Staff China & $0.23^{* * *}$ & $0.27^{* * *}$ & $0.23^{* * *}$ & $0.21^{* * *}$ & $0.27^{* * *}$ & $0.23^{* * *}$ & $0.26^{* * * *}$ & $0.07^{*}$ & 0.06 & $0.13^{* * *}$ & $0.11^{* *}$ & 0.04 & 0.01 & 0.02 & $0.15^{* * *}$ & $0.16^{* * *}$ & $0.15^{* * *}$ & $0.10^{* *}$ & $0.32^{* * *}$ & & \\
\hline 21. Staff HK & $0.08^{* *}$ & -0.02 & 0.01 & 0.01 & $0.08^{*}$ & $0.19^{* * *}$ & $0.07^{*}$ & 0.00 & -0.05 & -0.01 & 0.04 & 0.03 & 0.04 & 0.00 & 0.06 & 0.02 & $0.07^{*}$ & $0.29 * * *$ & $-0.34 * * *$ & $0.23 * * *$ & \\
\hline Mean & 5.02 & 5.00 & 5.40 & 4.96 & 4.57 & 4.07 & 4.25 & 4.39 & 4.15 & 4.50 & 4.63 & 4.30 & 4.35 & 4.19 & 4.37 & 4.36 & 4.55 & $\begin{array}{ll}16.16 \quad 0.7\end{array}$ & & 2.14 & 1.62 \\
\hline Std. Dev. & 1.67 & 1.69 & 1.59 & 1.63 & 1.67 & 1.98 & 1.71 & 1.04 & 1.20 & 1.07 & 1.00 & 1.15 & 1.24 & 1.29 & 1.15 & 1.14 & 1.10 & $13.72 \quad 0.4$ & & 0.99 & 0.85 \\
\hline
\end{tabular}

Note: Diagonal is square root of AVE. 
Table 2. Constructs and Items

\begin{tabular}{|c|c|c|c|c|c|}
\hline Construct and Items & $\begin{array}{c}\text { Factor } \\
\text { Loading }\end{array}$ & z-value & $\mathbf{R}^{2}$ Value & $\begin{array}{l}\text { Construct } \\
\text { Reliability }\end{array}$ & $\begin{array}{c}\text { Average } \\
\text { Variance } \\
\text { Extracted } \\
\text { (AVE) }\end{array}$ \\
\hline Organizational Control & & & & 0.89 & 0.67 \\
\hline Setting performance targets & 0.89 & & 0.76 & & \\
\hline Use performance-based rewards, appraisal & 0.74 & 20.58 & 0.55 & & \\
\hline Use formal systems, procedures and rules & 0.87 & 22.81 & 0.76 & & \\
\hline Detailed reporting on operations & 0.76 & 22.40 & 0.58 & & \\
\hline Transfer Success & & & & 0.89 & 0.80 \\
\hline We have succeeded in transferring operating practices & 0.80 & & 0.63 & & \\
\hline We have succeeded in transferring accounting practices & 0.64 & 16.67 & 0.41 & & \\
\hline We have succeeded in transferring HRM practices & 0.79 & 19.21 & 0.63 & & \\
\hline Human Capital Availability & & & & 0.92 & 0.85 \\
\hline Competent employees available & 0.90 & & 0.82 & & \\
\hline Competent managers available & 0.89 & 23.31 & 0.79 & & \\
\hline Human Capital Development & & & & 0.89 & 0.73 \\
\hline Development of local managerial skills in China & 0.95 & & 0.90 & & \\
\hline Development of local employee skills in China & 0.89 & 29.99 & 0.79 & & \\
\hline Human Capital Strength & & & & 0.86 & 0.68 \\
\hline $\begin{array}{l}\text { We know that the Mainland staff will always do a good } \\
\text { job }\end{array}$ & 0.88 & & 0.77 & & \\
\hline We can trust out Mainland staff not to let us down & 0.82 & 25.85 & 0.67 & & \\
\hline We can confidently delegate to our Mainland staff & 0.86 & 30.37 & 0.75 & & \\
\hline Subsidiary Performance & & & & 0.79 & 0.56 \\
\hline $\begin{array}{l}\text { Success in meeting the strategic objectives for our } \\
\text { activities in China }\end{array}$ & 0.90 & & 0.80 & & \\
\hline $\begin{array}{l}\text { Satisfaction with the performance of our activities in } \\
\text { China }\end{array}$ & 0.84 & 23.87 & 0.70 & & \\
\hline $\begin{array}{l}\text { Satisfaction with the performance of our activities in } \\
\text { China when compared with our competitors }\end{array}$ & 0.72 & 17.01 & 0.52 & & \\
\hline
\end{tabular}

Table 3. Goodness-of-Fit Statistics for Two Competing Specification of the Model

\begin{tabular}{lcccc}
\hline & $\begin{array}{c}\mathbf{0} \\
\text { Single Factor } \\
\text { Model }\end{array}$ & $\begin{array}{c}\mathbf{1} \\
\text { Measurement } \\
\text { Model (CFA) }\end{array}$ & $\begin{array}{c}\mathbf{2} \\
\text { Saturated Model }\end{array}$ & $\begin{array}{c}\mathbf{3} \\
\text { Theoretical Model }\end{array}$ \\
\hline Chi-square (d.f.) & 711.04 & 192.73 & 222.72 & 431.46 \\
GFI & $(119$ d.f.) & $(104$ d.f.) & $(108$ d.f.) & $(175$ d.f.) \\
GFI adjusted for d.f. & 0.73 & 0.93 & 0.91 & 0.91 \\
Parsimonious GFI & 0.65 & 0.89 & 0.88 & 0.88 \\
RMSEA & 0.57 & 0.63 & 0.65 & 0.69 \\
Comparative fit index & 0.09 & 0.04 & 0.04 & 0.05 \\
NNFI & 0.37 & 0.91 & 0.88 & 0.80 \\
Parsimonious NFI & 0.28 & 0.88 & 0.85 & 0.76 \\
\hline
\end{tabular}

Note: Saturated Model has Control, Human Capital Availability and Human Capital Development each linked to Transfer Success and Human Capital Strength. 